\title{
Prediksi Modulus Elastisitas Batuan Utuh dan Modulus Deformasi Massa Batuan dari Kurva Perilaku Konstitutif
}

\author{
Prediction of Modulus of Elasticity of Intact Rock and Rock Mass \\ Deformation Modulus from Constitutive Behavior Curves
}

\author{
Sari Melati ${ }^{1 *}$, Riswan $^{1}$ \\ ${ }^{1}$ Program Studi Teknik Pertambangan, Fakultas Teknik Universitas Lambung Mangkurat \\ Jl. Jend. Ach. Yani KM 36, Banjarbaru, Kalimantan Selatan, 70714 \\ *Alamatemail:sari@ulm.ac.id
}

\begin{abstract}
Abstrak - Penelitian ini bertujuan untuk memprediksi nilai modulus elastisitas batuan utuh dan modulus deformasi massa batuan. Pemboran inti pada batulempung di kedalaman 35, 42, dan 60 meter serta batubara di kedalaman 164 dan 181 meter telah dilakukan untuk mendapatkan contoh batu berbentuk silinder. Kemudian gaya diukur dan perpindahan titik diamati selama contoh diuji kuat tekan uniaksial. Selanjutnya regangan dan tegangan dihitung untuk membangun kurva perilaku konstitutif. Modulus elastisitas batuan utuh diprediksi dari Modulus Young Rata-rata karena tipe kurva teganganregangan contoh batubara dan batulempung yang diuji termasuk fase elastik pendek. Modulus deformasi massa batuan diprediksi dari Modulus Young Sekan yang diukur dari tegangan nol sampai lima puluh persen dari tegangan puncak. Hasil penelitian menunjukan bahwa Modulus Young contoh batubara 0.30 dan 0.44 GigaPascal (GPa), sedangkan contoh batulempung 3.92, 4.14, dan 4.28 GPa. Modulus deformasi massa batuan batubara diprediksi 0.11 dan 0.35 GPa, sedangkan modulus deformasi massa batuan batulempung diprediksi 2.40, 3.86, dan 4.46 GPa. Dengan demikian dapat dikatakan bahwa batuan sedimen di Formasi Tanjung Kalimantan Selatan memiliki karakteristik modulus deformasi massa batuan yang 20-63\% kurang dari modulus elastisitas batuan utuh. Mengingat studi mengenai topik tersebut masih terbatas jumlahnya, data empiris yang didapatkan dari penelitian ini sangat berharga untuk berbagai kepentingan di bidang mekanika batuan. Contoh terapannya yaitu modulus deformasi massa batuan sebagai parameter masukan pada analisis tegangan-regangan di sekitar bukaan tambang bawah tanah menggunakan permodelan numerik, penilaian kondisi tegangan insitu dan distribusi tegangan terinduksi melalui pemantauan pergerakan massa batuan, atau perhitungan energi regangan dari ledakan batuan (rock bursts).
\end{abstract}

Kata kunci: batuan utuh, massa batuan, mekanika batuan, modulus deformasi, modulus elastisitas

\begin{abstract}
This study predicts elasticity modulus of intact rock and deformation modulus of the rock mass. Core drilling on claystone at depths of 35, 42 and 60 meters and coal at depths of 164 and 181 meters operated to derive cylindrical rock samples. While uniaxial compressive strength tests had been conducting, the forces were measured and the point displacement was observed. Furthermore, strain and stress were calculated in order to the construction of constitutive behavior curves. The elasticity modulus of intact rock was predicted from Average Young Modulus because the stressstrain curves of coal and claystone tested samples classified as short elastic phase-type. Modulus of rock mass deformation was predicted from Secant Young Modulus, measured from zero to fifty percent of the peak stress. The results showed that Modulus Young coal samples were 0.30 and 0.44 Giga Pascal (GPa), while clay samples were 3.92, 4.14, and 4.28 GPa. Deformation modulus of coal rock mass was predicted 0.11 and $0.35 \mathrm{GPa}$, while the deformation modulus of claystone rock mass predicted to be 2.40, 3.86, and 4.46 GPa. It can be concluded that sedimentary rocks of the Tanjung Formation in South Kalimantan have characteristics modulus deformation of rock mass which was 20-63\% relatively less than modulus elasticity of intact rocks. In consideration that only a limited number of studies about this topic were reported, the empirical data obtained from this costlier research are worthies references in various interests of rock mechanics. Applied examples are deformation modulus of the rock mass as input parameters in stress-strain analysis around underground mine openings using numerical modeling, assessment of in situ stress conditions and induced stress distribution through monitoring rock mass movement, or calculating strain energy from rock bursts.
\end{abstract}

Keywords: deformation modulus, elasticity modulus, intact rock, rock mass, rock mechanics

(C) 2019 Jurnal Jejaring Matematika dan Sains. This work is licensed under a $\underline{C C B Y-N C 4.0}$

Sejarah Artikel

Diterima : 16 November 2019

Disetujui : 24 Desember 2019 


\section{PENDAHULUAN}

Dua dari enam belas tujuan pembangunan berkelanjutan yaitu ; memastikan akses energi yang terjangkau, bisa diandalkan, berkelanjutan dan modern; pembangunan infrastruktur yang kuat, mempromosikan industrial berkelanjutan dan mendorong inovasi. Hal ini menyebabkan konstruksi struktur pada batuan menjadi sesuatu yang tidak dapat dihindari, misalnya untuk memperoleh penggalian lubang bukaan tambang untuk mengambil batubara, gas, mineral; pembangunan terowongan transportasi bawah tanah, atau pembuatan ruang-ruang bawah tanah sesuai konsep kota pintar yang ramah lingkungan. Model massa batuan yang representatif menjadi kunci keberhasilan perancangan, sehingga sangat penting bagi rock engineer untuk mampu mendapatkan parameter sifat mekanik yang sesuai dengan kondisi massa batuan sebenarnya. Batuan sebagai bahan alam memiliki karakteristik sifat fisik, mekanik, dan kimiawi yang tidak dapat dirancang sebagaimana halnya material buatan. Salah satu parameter sifat mekanik tersebut adalah modulus elastisitas.

Sebelum modulus elastisitas batuan dibahas lebih jauh, terlebih dahulu ditinjau mengenai sifat elastis bahan secara umum. Sifat elastis yakni dapat melentur jika diberi gaya dan kembali ke keadaan semula ketika gaya ditiadakan [1]. Hampir semua bahan memperlihatkan sifat elastisitas. Ada bahan yang sangat elastis seperti karet dan ada yang kurang elastis seperti keramik. Ada benda yang sangat mudah diubah-ubah panjangnya, dan ada yang sangat sulit diubah panjangnya. Benda yang bentuknya mudah diubah oleh gaya dikatakan lebih elastis. Untuk membedakan bahan berdasarkan keelastisannya, maka didefinisikan besaran yang namanya Modulus Young. Benda yang lebih elastis (lebih lunak) memiliki modulus elastis yang lebih kecil [2].

Obyek penyelidikan di bidang ilmu Mekanika Batuan dibagi atas batuan utuh dan massa batuan. Massa batuan di alam terdiri dari sekelompok batuan utuh dan masingmasing dipisahkan oleh diskontinuitas[3]. Blok-blok batuan utuh dapat berukuran dari beberapa milimeter sampai beberapa meter. Propertis batuan utuh dibangun oleh sifat fisik bahan pembentuk dan keterikatannya [4]. Kekuatan massa batuan dalam skala yang lebih besar dikontrol oleh karakteristik diskontinuitas, mineral, serta persintensi, frekuensi, dan posisi diskontinuitas[3].

Komisi terminologi International Society for Rock Mechanics (ISRM) menerbitkan definisi modulus sebagai berikut.

- Modulus of deformation : the ratio of stress to corresponding strain during loading of a rock mass including elastic and inelastic behaviour

- Modulus of elasticity or Young Modulus : the ratio of stress to corresponding strain below the proportionality limit of a material. [3]

Deformabilitas massa batuan direpresentasikan oleh sebuah modulus yang menjelaskan hubungan antara beban dan deformasi yang dihasilkan. Padahal massa batuan tidak ber-deformasi secara elastik sehingga penggunaan terminologi modulus deformasi lebih cocok daripada Modulus Young.
Sampai saat ini, penentuan modulus deformasi massa batuan menjadi fokus penelitian yang menarik karena merupakan satu tahapan penting dalam perancangan dan konstruksi struktur pada batuan. Berbagai pendekatan terbaru di era industri 4.0 menjelang era industri 5.0 terus dikembangkan, di antaranya algoritma optimasi evolusioner [5], neural network, fuzzy inference, genetic programming[6-7], fuzzy clustering [8], dan permodelan numerik [9]. Penggunaan metode statistik konvensional pun masih perlu diuji kelayakannya [10]. Semua itu tentu tidak terlepas dari tersedianya data empirik yang memadai. Data ini dapat diperoleh dari proyek pembangunan tambang bawah tanah [11-13], tambang terbuka[14-15], terowongan[10,16], situs panas bumi[17], dan lain-lain. Sekumpulan data empiris ini kemudian dianalisis, dibandingkan, dan dijadikan acuan untuk kepentingan proyek konstruksi pada massa batuan di lokasi lain[18-21]. Oleh karena itu kebutuhan akan data deformabilitas batuan adalah hal mutlak yang harus dipenuhi. Pembangunan model yang representatif sangat bergantung pada ketersediaan data dalam jumlah besar (big data).

Meskipun sepertinya ada jarak yang terlalu jauh antara perkembangan penelitian di negara maju dengan kondisi di daerah, celah tersebut harus tetap diisi. Mengingat potensi batubara yang terdapat di Kalimantan Selatan masih sangat besar, yaitu sekitar 4.2 miliar ton [22]. Dengan produksi batubara mencapai 150 juta ton pada tahun 2018, Kalimantan Selatan telah tercatat sebagai provinsi penghasil batubara terbesar kedua setelah Kalimantan Timur. Meskipun produksi batubara dibatasi [23], batubara tetap menjadi komoditas ekspor andalan Kalimantan Selatan selain crude palm oil (CPO) [24]. Prospek pemanfaatan batubara di masa yang akan datang seiring berkembangnya teknologi tambang batubara bawah tanah, pencairan, atau gasifikasi batubara, menjadikan ketersediaan data untuk keperluan rekayasa dan perancangan menjadi tantangan tersendiri. Demi menjawab tantangan tersebut, maka setiap data yang diperoleh, sesedikit apa pun jumlahnya, harus terdokumentasi dan dimanfaatkan dengan baik.

Penelitian ini bertujuan untuk memprediksi nilai modulus elastisitas batuan utuh dan modulus deformasi massa batuan. Modulus deformasi diperlukan untuk mengetahui respon batuan terhadap gaya yang dikenakan kepadanya, terlebih gaya karena gangguan pembangunan struktur. Contoh terapannya yaitu modulus deformasi massa batuan sebagai parameter masukan pada analisis tegangan-regangan di sekitar bukaan tambang bawah tanah menggunakan permodelan numerik, penilaian kondisi tegangan insitu dan distribusi tegangan terinduksi melalui pemantauan pergerakan massa batuan, atau perhitungan energi regangan dari ledakan batuan (rock bursts).

\section{METODE PENELITIAN}

\section{A. Bahan}

Batu yang ingin diketahui elastisitasnya adalah batubara dan batulempung. Contoh batubara didapatkan dari pemboran inti secara langsung di lokasi tambang batubara 
yang terletak di daerah Pengaron, Kabupaten Banjar Provinsi Banjar. Contoh batulempung diambil dari lokasi tambang lainnya, tetapi secara geologi masih dalam formasi yang sama, yaitu Formasi Tanjung. Contoh batu diambil dari Formasi Tanjung Kalimantan Selatan. Batubara Formasi Tanjung terdiri atas lapisan-lapisan tipis $(<7 \mathrm{~m})$, berlapis sangat baik, keras, padat, lapisannya relatif menerus, nilai kalori $>6.000 \mathrm{kal} / \mathrm{g}$ [25]. Contoh yang dibawa dari lapangan berbentuk bongkah. Selanjutnya bongkah tersebut dibor untuk mendapatkan inti berbentuk silinder.

Sebelum pengujian, contoh batu dipreparasi terlebih dahulu. Sesuai dengan standar uji yang dijadikan acuan, yaitu International Society for Rock Mechanics (ISRM) Suggested Method for Determining the Uniaxial Compressive Strength and Deformability of Rock Materials, kualitas contoh batu uji harus memenuhi persyaratan-persyaratan berikut.

- Diameter contoh batu uji berbentuk silinder sebaiknya minimal berukuran NQ atau $54 \mathrm{~mm}$. Diameter dalam mata bor inti yang digunakan sudah memenuhi syarat ini, yaitu $55 \mathrm{~mm}$ di laboratorium dan $60 \mathrm{~mm}$ di lapangan.

- Perbandingan panjang dengan diameter (L/D) contoh batu antara 2 sampai 3. Perbandingan 2.5 lebih baik dan disukai. Jika perbandingan kurang dari 2, kuat tekan contoh lebih besar karena tegangan dari atas dan bawah saling bertemu. Sebaliknya jika perbandingan L/D lebih dari 2.5, contoh batu uji akan lebih cepat mengalami keruntuhan dan nilai kuat tekan uniaksial menjadi lebih kecil. Melalui pemilahan terhadap contoh, terpilih beberapa bagian contoh inti batu yang layak. Selanjutnya inti silinder dipotong menggunakan grinder untuk memenuhi syarat. Jumlah contoh batu yang layak uji semakin terbatas karena batubara dan batulempung ini memiliki retakan-retakan yang cukup rapat sehingga panjangnya bahkan tidak cukup untuk memenuhi perbandingan 2 .

- Kerataan kedua permukaan contoh batu uji harus mencapai $0.02 \mathrm{~mm}$ dan tidak melenceng dari sumbu tegak lurus lebih dari $0.05 \mathrm{~mm}$ dalam $50 \mathrm{~mm}$. Sisi

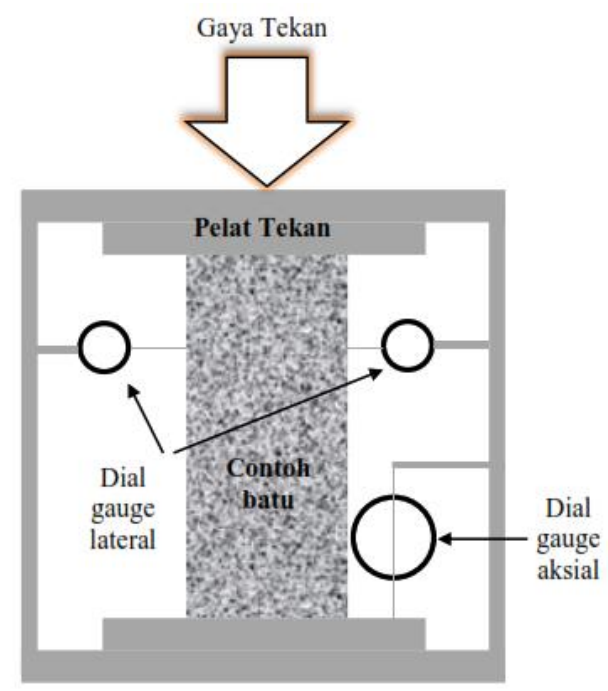

Gambar 1. Skema penempatan contoh batu ilustrasi gaya pada uji kuat tekan uniaksial panjang atau permukaan selimut tabung harus lurus dan kelurusannya sepanjang contoh tidak melenceng lebih dari $0.3 \mathrm{~mm}$. Dengan demikian, pemotongan diusahakan serata mungkin agar tekanan tersebar secara merata dan permukaan batu mengalami tegangan yang sama di seluruh permukaan kontak. Kehalusan dan kerataan permukaan contoh batu uji diperiksa dengan squareness gauge dan nivo tabung.

\section{B. Metode}

Peralatan untuk uji kuat tekan uniaksial ini ada 4, yaitu alat uji kuat tekan, mesin hidrolik, dial penunjuk gaya, dan dial gauge. Contoh batu uji ditempatkan di antara dua plat penekan. Mesin hidrolik dihidupkan untuk menggerakkan piston sampai pelat penekan atas benarbenar menyentuh permukaan contoh batu uji secara merata. Dial gauge yang berfungsi untuk mengukur perpindahan aksial dan lateral, dipasang sebagaimana terlihat pada Gambar 1 dan jarumnya diatur hingga menunjuk posisi nol.

Demi menjaga kesesuaian laju tegangan dengan standar uji laju tegangan antara 0.5-1.0 MegaPascal/detik atau uji berlangsung antara 3-5 menit, stopwatch sangat diperlukan untuk mencatat waktu pembebanan. Ketika jarum hitam pada alat pengukur gaya mulai bergerak meninggalkan titik nol, pembebanan aksial dimulai dan stopwatch dihidupkan. Perpindahan aksial dan lateral dicatat saat jarum hitam pada alat pengukur gaya berada tepat di nilai-nilai tertentu, setiap 2 kilo Newton pada batulempung, setiap $0.625 \mathrm{kN}$ pada batubara.

Tegangan tekan $\sigma$ sebagai perbandingan antara gaya tekan $\mathrm{F}$ dengan luas permukaan A dihitung menggunakan persamaan (1). Permukaan contoh yang mengalami penekanan berpenampang lingkaran sehingga luasnya dihitung menggunakan persamaan (2), dimana D adalah diameter contoh $(54 \mathrm{~mm})$ dan konstanta $\pi$ senilai 3.14 atau $22 / 7$.

$$
\begin{aligned}
& \sigma_{\mathrm{c}}=\frac{F}{A} \\
& \mathrm{~A}=0.25 \pi \mathrm{D}^{2}
\end{aligned}
$$

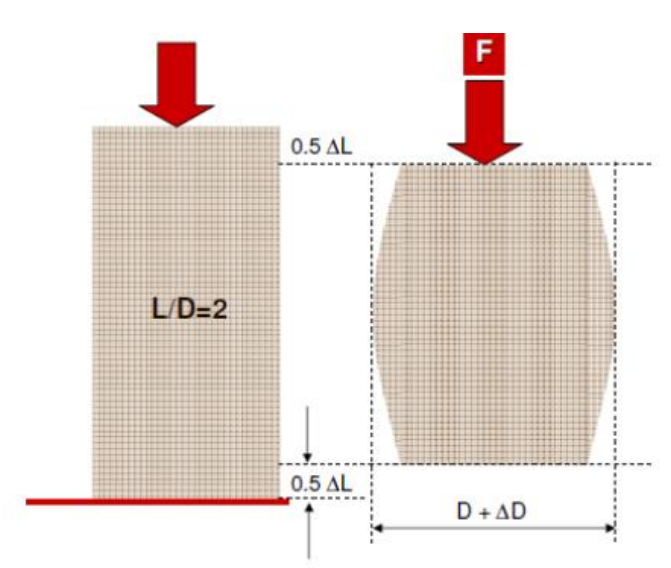

Gambar-2. Perubahan bentuk contoh batu akibat penekanan aksial 

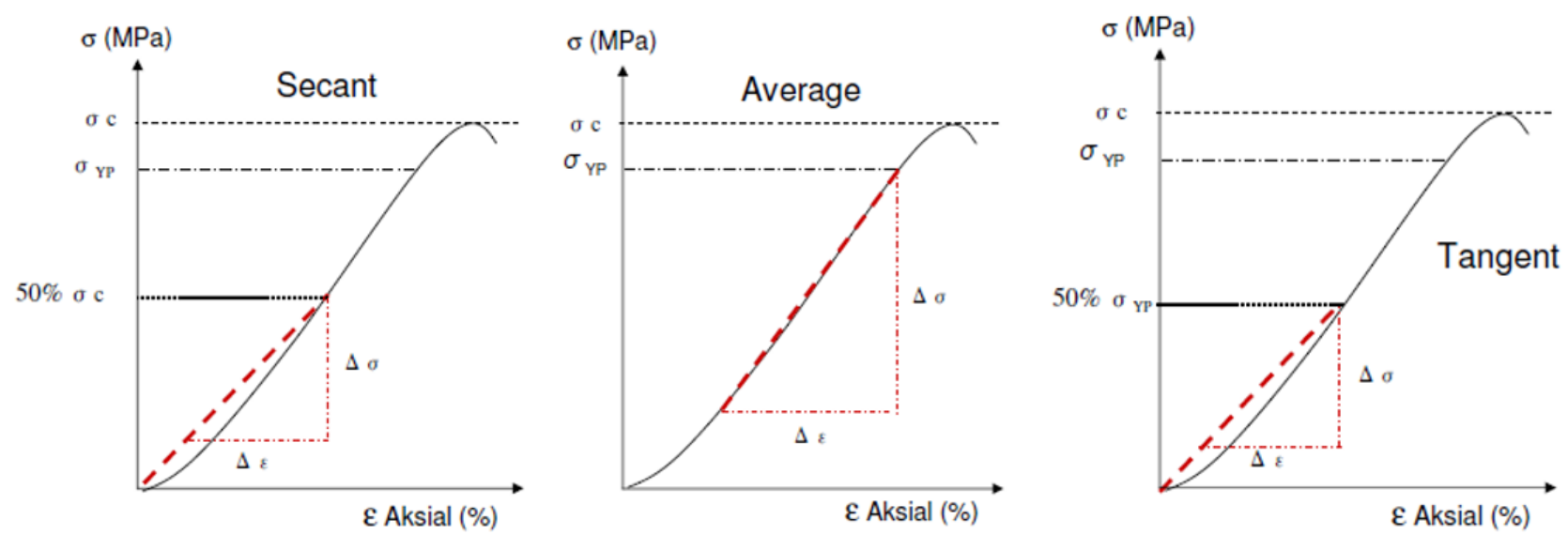

Gambar 3. Penentuan Modulus Young Sekan, Tangen, dan Rerata

Setelah penekanan, contoh batu akan mengalami pemendekan sepanjang sumbu aksial dan penggelembungan secara lateral. Bentuk akhir batu uji akan berubah seperti gentong sebagaimana terlihat pada Gambar 2. Dari perubahan bentuk ini yang diukur sebagai perpindahan aksial dan perpindahan lateral menggunakan dial gauge, regangan contoh dapat dihitung. Regangan aksial $\varepsilon_{\mathrm{a}}$ merupakan perbandingan antara perubahan panjang $\Delta \mathrm{L}$ dengan panjang awal contoh batu L. Regangan lateral $\varepsilon_{1}$ merupakan perbandingan antara perubahan panjang $\Delta \mathrm{D}$ dengan diameter awal contoh batu $\mathrm{D}$. Regangan volumetrik $\varepsilon_{\mathrm{v}}$ dihitung dari dua kali regangan lateral ditambah regangan aksial. Perhitungan regangan menggunakan persamaan (3), (4), dan (5).

$$
\begin{aligned}
& \varepsilon_{\mathrm{a}}=\frac{\Delta \mathrm{L}}{L} \\
& \varepsilon_{\mathrm{l}}=\frac{\Delta \mathrm{D}}{D} \\
& \varepsilon_{\mathrm{v}}=2 \varepsilon_{1}+\varepsilon_{\mathrm{a}}
\end{aligned}
$$

Modulus Young didapatkan dari penggambaran kurva perilaku konstitutif tegangan-regangan. Tegangan dalam satuan MPa digambar pada sumbu Y. Regangan aksial digambar pada sumbu $X$ postif, sementara regangan lateral digambar pada sumbu Y negatif. Modulus Young merupakan besarnya tegangan $\Delta \sigma$ untuk meregangkan batuan $\Delta \varepsilon_{a}$ dan dihitung menggunakan persamaan (6).

$$
\mathrm{E}=\frac{\Delta \sigma}{\Delta \varepsilon_{a}}
$$

Modulus elastisitas batuan utuh $\mathrm{E}_{\mathrm{i}}$ diambil dari nilai Modulus Young rata-rata, yaitu Modulus Young yang diukur dari rata-rata kemiringan kurva atau bagian linier yang terbesar dari kurva. Sedangkan modulus deformasi massa batuan $\mathrm{E}_{\mathrm{rm}}$ diperkirakan dari Modulus Young
Sekan, yaitu Modulus Young yang diukur dari tegangan = 0 sampai nilai tegangan tertentu $50 \% \sigma_{c}$. Untuk lebih memahami perbedaan kedua penentuan Modulus Young, Rai dkk [3] telah menggambarkannya melalui 3 cara (Gambar 3).

Terakhir, hubungan antara modulus elastisitas batuan utuh $\mathrm{E}$ dan modulus deformasi massa batuan $\mathrm{E}_{\mathrm{rm}}$ dihitung menggunakan persamaan (7), dimana $\mathrm{k}$ merupakan kostanta yang menyatakan hubungan antara keduanya yang ditulis pada persamaan (8).

$$
\begin{aligned}
& \mathrm{E}_{\mathrm{rm}}=\mathrm{k} E_{i} \\
& \mathrm{k}=\frac{E_{r m}}{E_{i}}
\end{aligned}
$$

\section{HASIL DAN PEMBAHASAN}

Contoh batulempung dan batubara pada uji kuat tekan uniaksial ini pecah pada gaya tertinggi antara 48-58 $\mathrm{kN}$ dan 7.5-9.38 kN. Sehingga dapat dikatakan bahwa tegangan tekan uniaksial puncak atau kuat tekan uniaksialnya sebesar $19.86-23.88 \mathrm{MPa}$ dan $2.65-3.2$ MPa (Tabel-1). Pertambahan regangan di akhir tahap pengujian sangat bervariasi, dari $0.6-2.32 \%$ pada sumbu aksial, dan $0.08-1.33 \%$ pada sumbu lateral. Besarnya regangan sangat ditentukan oleh deformabilitas batu. Deformabilitas batu sendiri merupakan karakteristik khusus yang dipengaruhi oleh banyak faktor, diantaranya kehadiran rekahan mikro dan sifat kegetasan batu. Demi mempelajari fenomena ini secara lebih mendalam, hubungan antara tegangan-regangan diperlihatkan pada pada Gambar 4 dan Gambar 5.

Tabel 1. Rekapitulasi Perhitungan Tegangan dan Regangan Puncak

\begin{tabular}{|c|c|c|c|c|c|c|c|c|c|}
\hline $\begin{array}{c}\text { Kode } \\
\text { contoh }\end{array}$ & $\begin{array}{c}\mathrm{D} \\
(\mathrm{mm})\end{array}$ & $\begin{array}{c}\mathrm{A} \\
\left(\mathrm{mm}^{2}\right)\end{array}$ & $\begin{array}{c}\mathrm{F} \\
(\mathrm{kN})\end{array}$ & $\begin{array}{c}\sigma_{\mathrm{c}} \\
(\mathrm{MPa})\end{array}$ & $\begin{array}{c}\mathrm{L} \\
(\mathrm{mm})\end{array}$ & $\begin{array}{c}\Delta \mathrm{L} \\
(\mathrm{mm})\end{array}$ & $\varepsilon_{\mathrm{a}}(\%)$ & $\begin{array}{c}\Delta \mathrm{D} 1+\Delta \mathrm{D} 2 \\
(\mu \mathrm{m})\end{array}$ & $\varepsilon_{1}(\%)$ \\
\hline Cs-4 & 55.6 & 2429.81 & 58 & 23.88 & 113.6 & 0.7 & 0.62 & 139 & -0.25 \\
\hline Cs-15 & 55.43 & 2415.26 & 50 & 20.71 & 120.17 & 1.14 & 0.87 & -0.20 & -0.36 \\
\hline Cs-18 & 55.47 & 2418.17 & 48 & 19.86 & 118.17 & 0.69 & 0.58 & -0.16 & -0.28 \\
\hline C1-06 & 61.1 & 2930.57 & 9.38 & 3.20 & 142.3 & 3.30 & 2.32 & -0.81 & -1.33 \\
\hline D-08 & 60 & 2826 & 7.50 & 2.65 & 130.9 & 0.78 & 0.6 & -0.05 & -0.08 \\
\hline
\end{tabular}


Perilaku konstitutif adalah gambaran secara kualitatif hubungan dasar antara tegangan dan regangan dalam batuan di bawah kondisi pembebanan. Variasi dari model-model kostitutif menggambarkan reaksi bergantung dan tidak bergantung terhadap waktu dari batuan pada saat menerima beban [26].

Gambar 4 memperlihatkan kurva perilaku konstitutif contoh batubara C1-06 mengalami regangan aksial seketika $0.85 \%$ pada tegangan $0.21 \mathrm{MPa}$. Setelah tegangan naik lagi ke $0.64 \mathrm{MPa}$, contoh meregang hingga $1.33 \%$. Kemiringan kurva berubah lebih tegak hingga contoh pecah. Fase awal dimana kurva tegangan-regangan cenderung landai disebut fase penutupan rekahan. Pada fase tersebut, tegangan tekan bekerja untuk menutup pori dan rekahan mikro yang terdapat dalam contoh batu. Setelah seluruh pori dan rekahan mikro tertutup, butirbutir batu telah rapat sehingga kekakuan atau deformabilitasnya meningkat. Diperlukan tegangan lebih besar $(2.56 \mathrm{MPa})$ untuk membuat batu meregang $0.1 \%$. Pola yang mirip ditunjukan oleh kurva tekananpembesaran volumetrik hasil pengukuran modulus deformasi menggunakan menard pressuremeter di massa batuan andesit sekitar shaft tambang bawah tanah. Kemiringan kurva berubah setelah mengalami tekanan 2 $\mathrm{MPa}$ dan pembesaran volumetrik $5 \times 10 \mathrm{~m}^{3}$ [11].

Fase penutupan rekahan ini juga teridentifikasi dengan mudah pada kurva contoh batulempung C-15, karena kemiringan kurva berubah lebih tegak setelah contoh meregang $0.27 \%$. Berbeda halnya dengan tiga contoh lain yang dari awal kemiringan kurva aksialnya tidak menunjukan perbedaan dan cenderung tetap, fase penutupan rekahan lebih sulit diidentifikasi.

Griffith (1921) menyatakan bahwa arah retakan dari sebuah material getas akan sesuai dengan tegangan utama maksimumnya. Pada uji kuat tekan uniaksial, tegangan utama maksimum tegak searah panjang contoh (sumbu aksial). Seharusnya apabila contoh batu ini tergolong material getas, bentuk pecah berupa axial splitting. Gambar-6 memperlihatkan bentuk pecah contoh batubara D-08 merupakan homogeneous shear, sementara bentuk pecah contoh batulempung Cs-18 merupakan combination axial \& local shear. Bentuk pecah seperti ini sesuai dengan tipe pecah batu hasil uji kuat tekan uniaksial menurut Kramadibrata (1990). Lebih jauh lagi dijelaskan, bahwa keruntuhan geser terjadi ketika rekahan tunggal atau beberapa rekahan mempropogasi ke seluruh contoh batuan, sehingga terjadi pergeseran sepanjang rekahan yang terbentuk. Bidang geser tempat terjadinya geseran akan membentuk sudut tertentu terhadap tegangan aksial yang diberikan. Ini yang terlihat pada contoh batubara D08. Artinya telah tersedia rekahan tunggal atau beberapa rekahan di dalam contoh. Axial splitting terbentuk jika rekahan yang terjadi searah atau paralel dengan arah tegangan aksial. Ikatan butiran pada contoh akan runtuh karena tarikan. Multiple cracking terjadi ketika contoh pecah sepanjang banyak bidang pada arah yang tidak beraturan. Ini yang terlihat pada contoh batulempung Cs18.

Apabila nilai kuat tekan uniaksial $\sigma_{\mathrm{c}}$ dan Modulus Young $\mathrm{E}_{\mathrm{i}}$ diplot pada diagram hubungan kekuatan dan deformabilitas batuan Deere \& Miller $^{[4]}$, contoh batulempung dan batubara ini tergolong batu dengan kekuatan sangat lemah dan lunak karena kuat tekan uniaksialnya kurang dari $35 \mathrm{MPa}$ dan Modulus Young kurang dari $10 \mathrm{GPa}$. Adapun menurut ISRM (1981), contoh batubara termasuk sangat lemah (very weak) karena kuat tekan uniaksialnya ada dalam rentang nilai 1$5 \mathrm{MPa}$ [3]. Contoh batulempung tergolong lemah (weak) karena kuat tekannya antara 5-25 $\mathrm{MPa}$.

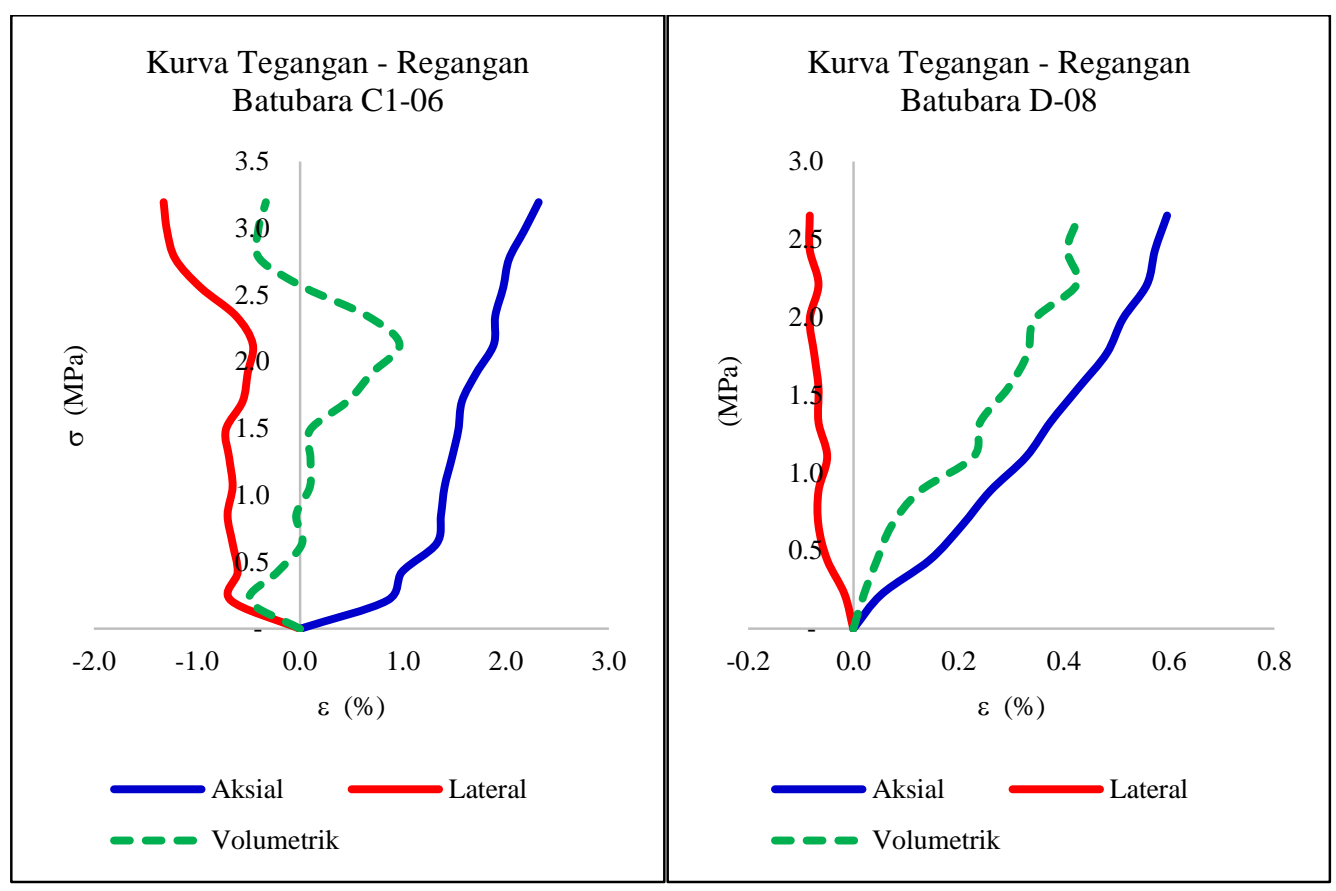

Gambar 4. Kurva lengkap perilaku konstitutif contoh batubara 

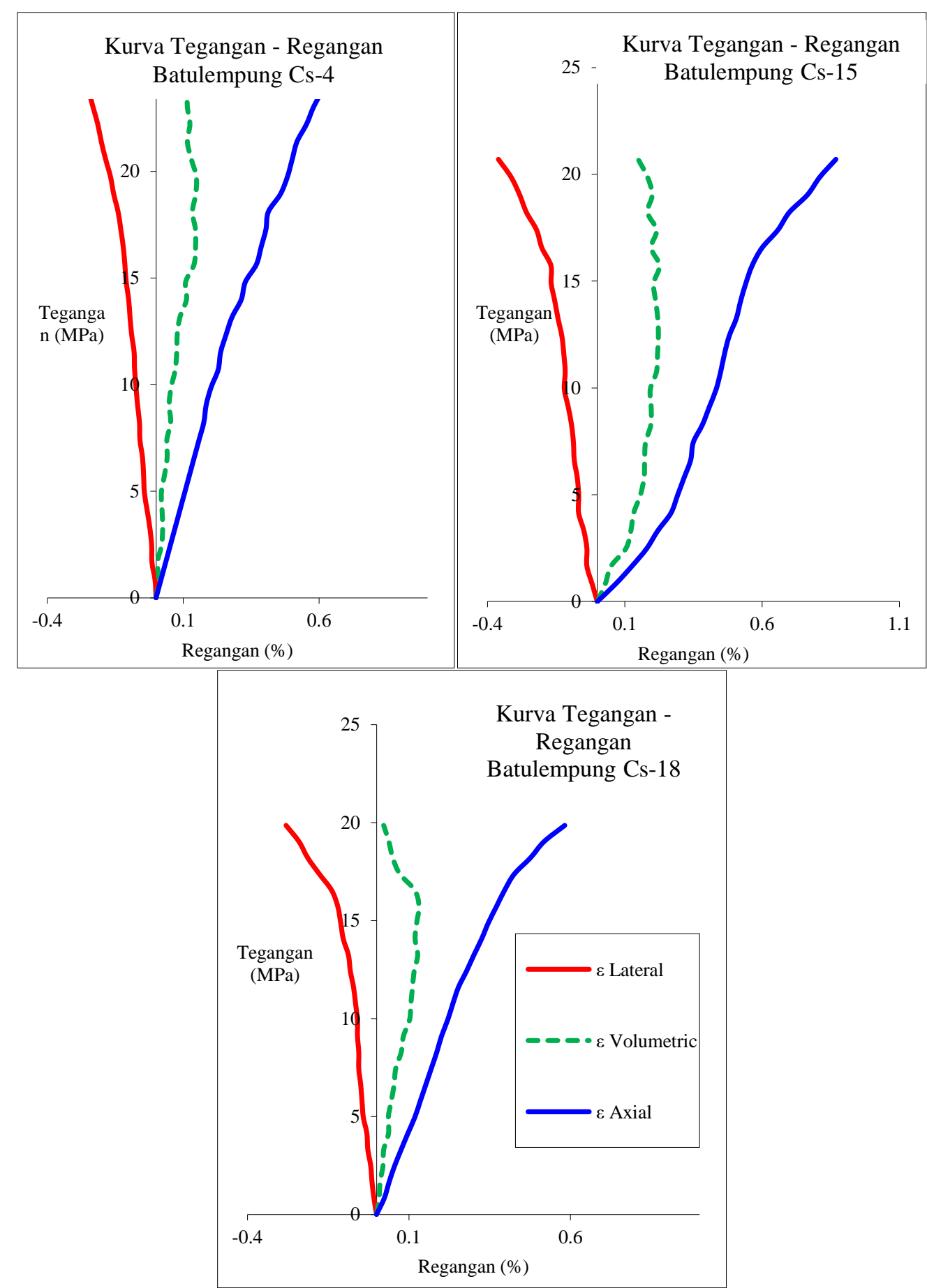

Gambar 5. Kurva lengkap perilaku konstitutif contoh batulempung

Tabel 2. Rekapitulasi Modulus Elastisitas dan Modulus Deformasi

\begin{tabular}{|c|c|c|c|c|c|c|c|c|}
\hline \multirow{2}{*}{$\begin{array}{l}\text { Kode } \\
\text { Contoh }\end{array}$} & \multicolumn{3}{|c|}{ Rata-Rata } & \multicolumn{3}{|c|}{ Secant } & \multirow{2}{*}{$\begin{array}{c}E_{\mathrm{i}}-\mathrm{E}_{\mathrm{rm}} \\
(\mathrm{GPa})\end{array}$} & \multirow[t]{2}{*}{$\mathrm{k}=\mathrm{E}_{\mathrm{rm}} / \mathrm{E}_{\mathrm{i}}$} \\
\hline & $\begin{array}{c}\Delta \sigma \\
(\mathrm{MPa})\end{array}$ & $\Delta \varepsilon(\%)$ & $\begin{array}{c}\mathrm{E}_{\mathrm{i}} \\
(\mathrm{GPa})\end{array}$ & $\Delta \sigma(\mathrm{MPa})$ & $\begin{array}{c}\Delta \varepsilon \\
(\%)\end{array}$ & $\begin{array}{c}\mathrm{E}_{\mathrm{rm}} \\
(\mathrm{GPa})\end{array}$ & & \\
\hline Cs-4 & 13.17 & 0.31 & 4.28 & 14.00 & 0.31 & 4.46 & -0.18 & -0.04 \\
\hline Cs-15 & 11.60 & 0.31 & 3.69 & 10.77 & 0.45 & 2.40 & 1.29 & 0.35 \\
\hline Cs-18 & 13.24 & 0.32 & 4.14 & 10.76 & 0.24 & 4.56 & -0.42 & -0.10 \\
\hline C1-06 & 1.92 & 0.65 & 0.30 & 1.70 & 1.57 & 0.11 & 0.19 & 0.63 \\
\hline D-08 & 1.55 & 0.35 & 0.44 & 1.33 & 0.37 & 0.35 & 0.09 & 0.20 \\
\hline
\end{tabular}


Dari kurva pada Gambar-4 dan Gambar-5 didapatkan modulus elastisitas batuan utuh contoh batubara 0.30 dan $0.44 \mathrm{GPa}$. Pada Tabel 2 tercantum modulus elastisitas contoh batulempung 3.69, 4.14, dan 4.28 GPa. Modulus deformasi massa batuan contoh batubara $0.11 \mathrm{GPa}$ dan $0.35 \mathrm{GPa}$, contoh batulempung 2.40, 4.46, dan 4.56 GPa. Pengujian pada tiga contoh batu, yaitu Cs-15, C1-06, dan D-08 sesuai dengan pernyataan umum bahwa [3] modulus deformasi massa batuan akan lebih rendah dibanding modulus elastisitas batuan utuh. Dua contoh lainnya, yaitu contoh Cs-4 dan Cs-18 merupakan kasus khusus dimana kekakuan kurva pada fase awal pemberian tegangan justru lebih tegak dibanding kurva fase elastis. Nilai $k$ dari hubungan antara $E_{r m}$ dan $E_{i}$ dimana $E_{\mathrm{i}}>E_{\mathrm{rm}}$ ialah 0.20, 0.35, dan 0.65. Jika dirataratakan, $\mathrm{E}_{\mathrm{rm}}=0.39 \mathrm{E}_{\mathrm{i}}$.

Hasil ini cukup mendekati apabila dibandingkan dengan penelitian sebelumnya yang pernah dilakukan dengan membandingkan Modulus Young dari hasil uji laboratorium $\left(\mathrm{E}_{\mathrm{lab}}\right)$ dengan modulus deformasi massa batuan $\left(\mathrm{E}_{\mathrm{m}}\right)$ dari pengujian insitu di tambang bawah tanah [3]. Persamaan empiris yang dibangun dari penelitian tersebut yaitu $\mathrm{E}_{\mathrm{m}}=0.469 \mathrm{E}_{\mathrm{i}}$. Dengan demikian, prediksi modulus deformasi massa batuan melalui pengukuran Modulus Young Sekan pada kurva konstitutif yang didapatkan dari uji kuat tekan uniaksial di laboratorium dalam penelitian ini dapat digunakan untuk keperluan praktis di awal desain apabila pengujian insitu belum memungkinkan untuk terlaksana.
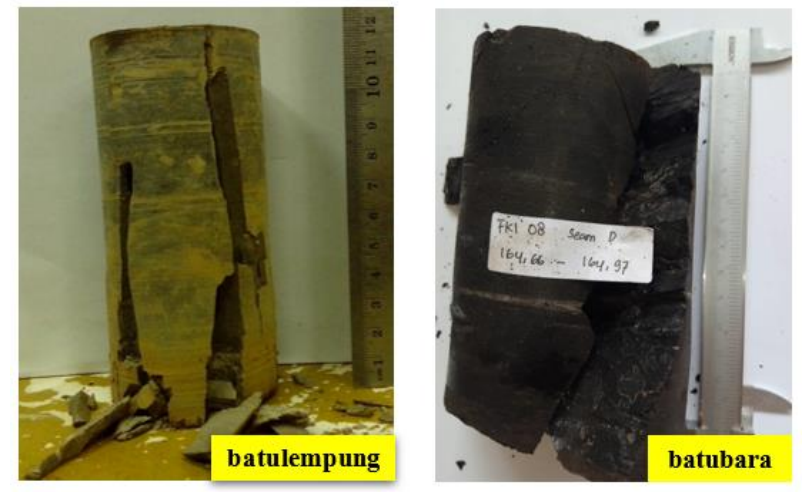

Gambar 6. Bentuk pecah contoh batu dari uji kuat tekan uniaksial

\section{SIMPULAN}

Modulus elastisitas batuan utuh dan modulus deformasi massa batuan dari contoh batulempung dan batubara Formasi Tanjung Kalimantan Selatan telah berhasil diprediksi melalui penggambaran kurva perilaku konstitutif yang menunjukan hubungan teganganregangan pada uji kuat tekan uniaksial. Perbedaan relatif antara modulus deformasi massa batuan dengan modulus elastisitas batuan utuh didapatkan cukup bervariasi dengan perbedaan antara $-4 \%$ sampai dengan $63 \%$. Mengingat laporan studi mengenai salah satu karakteristik mekanik batuan ini masih jarang ditemukan, data empiris yang didapatkan dari penelitian ini sangat berharga untuk berbagai kepentingan di bidang mekanika batuan. Disarankan untuk mengeksplorasi pengaruh anisotropi terhadap modulus elastisitas batuan di perlapisan batuan sedimen pada riset selanjutnya.

\section{REFERENSI}

[1] R.A. Sani, "Elastisitas dan Gaya Pegas," Fisika Terapan Smart. Tangerang : Tira Smart, 2017, 52.

[2] M. Abdullah, "Benda Tegar dan Elastisitas," Fisika Dasar I. Bandung : Institut Teknologi Bandung, 2016, 670-671.

[3] M.A. Rai, S. Kramadibrata, dan R. K. Wattimena, Mekanika Batuan. Bandung : Penerbit ITB, 2014,19-20, $175-176$

[4] L. Zhang, "Intact Rock," Engineering Properties of Rock. Elsevier. 2017

[5] A. Majdi and M. Beiki, "Applying evolutionary optimization algorithms for improving fuzzy C-mean clustering performance the deformation modulus of rock mass," International Journal of Rock Mechanics and Mining Sciences, Vol. 113, P. 172-182, January 2019.

[6] S. Alemdag, Z. Gurucak, A. Cevik, F. Cabalar, C. Gokceoglu, "Modeling deformation modulus of a stratified sedimentary rock mass using neural network, fuzzy inference, and genetic programming," Engineering Geology, Vol. 203. P. 70-82. March 2016.

[7] M. Beiki, A. Bashari, and A. Majdi, "Genetic programming approach for estimating the deformation modulus of rock mass using sensitivity analysis by neural network," International Journal of Rock Mechanics and Mining Sciences, Vol. 47, P. 1091-1103, October 2010.

[8] A. Bashari, M. Beiki, A. Talebinejad, "Estimation of deformation modulus of rock masses by using fuzzy clustering-based modeling," International Journal of Rock Mechanics and Mining Sciences, Vol. 48, P. 1224-1234, December 2011.

[9] E. G. Ravandi, R. Rahmannejad, A. E. F. Monfared, E.G. Ravandi, "Application of numerical modeling and genetic programming to esimate rock mass modulus of deformation," International Journal of Rock Mechanics and Mining Sciences, Vol. 23, P. 733-737, 2013.

[10] H. Fatahi, Z. Varmazyari, N. Babanouri, "Feasibility of Monte Carlo simulation for predicting deformation modulus of rock mass," Tunneling and Underground Space Technology, Vol. 89, P. 151-156, July 2019.

[11] I.F. Oge, "Determination of deformation modulus in a weak rock mass by using menard pressuremeter," International Journal of Rock Mechanics and Mining Sciences, Vol. 112, P. 238-252, December 2018.

[12] B. Kavur, S. Cvitanovic, P. Hrzenjak, "Comparison between plate jacking and large flat jack test result of rock mass deformation modulus," International Journal of Rock Mechanics and Mining Sciences, Vol. 73, P. 102-114, January 2015.

[13] X. W. Jiang, L. Wan, X. S. Wang, X. Wu, X. Zhang. "Estimation of rock mass deformation modulus using variations in transmissivity and RQD with depth," International Journal of Rock Mechanics and Mining Sciences, Vol. 46, P. 1370-1377, December 2009.

[14] K. Sugawara, L. Farmarzi, N. Nakamura, "Determination of rock mass deformation modulus by means of traveling load test-Part II : Traveling load test in an open pit," International Journal of Rock Mechanics and Mining Sciences, Vol. 43, P. 192-202, February 2006. 
[15] K. Sugawara, L. Farmarzi, N. Nakamura, "Determination of rock mass deformation modulus by means of traveling load test-Part I : Theory of the traveling load test in an open pit," International Journal of Rock Mechanics and Mining Sciences, Vol. 43, P. 179-191, February 2006.

[16] A. E. Aladejare, Y. Wang, "Estimation of rock mass deformation modulus using indirect information from multiple sources," Tunneling and Underground Space Technology, Vol. 89, P. 151-156, March 2019.

[17] M.J. Heap, M. Villeneuve, T. Reuschle, "Rock mass strength and elastic modulus of the Buntsandstein : An important listostratigraphic unit for geothermal exploitation in the Upper Rhine Graben," Gheotermics, Vol. 77, P. 236-256, 2019.

[18] K. Karaman, F. Cihangir, A. Kesimal, "A comparative assesment of rock mass deformation modulus" International Journal of Rock Mechanics and Mining Sciences, Vol. 25, P. 735-740, 2015.

[19] C.O. Aksoy, M.Genis, O. Yilmaz, "A comparative study of the determination of rock mass deformation modulus by using different empirical approaches," Engineering Geology, Vol. 131-132, P. 19-28, 2012.

[20] M. Cai, P.K. Kaiser, H. Uno, Y. Tasaka, M. Minami. "Estimation o rock mass deformation modulus and strength of jointed hard rock masses using the GSI system," International Journal of Rock Mechanics and Mining Sciences, Vol. 41, P. 3-19, January 2004.
[21] X. Feng, R. Jimenez, "Estimation of deformation modulus of rock masses based on Bayesian model selection and Bayesian updating approach," Engineering Geology, Vol. 199. P. 19-27, December 2015.

[22] Anonim, "Cadangan Batubara Indonesia Sebesar 26 Miliar Ton", Arsip Berita Kementerian Energi dan Sumber Daya Mineral Republik Indonesia, Tersedia: https://www.esdm.go.id/id/media-center/arsipberita/cadangan-batubara-indonesia-sebesar-26-miliar-ton [Diakses: 1 November 2019].

[23] D. Susanto, "Kalsel Batasi Produksi Batubara," Media Indonesia, 30 Agustus 2019 [Online]. Tersedia: https://mediaindonesia.com/read/detail/256425-kalselbatasi-produksi-batu-bara [Diakses : 1 November 2019].

[24] D. Susanto, "Ekspor Kalsel Terus Tumbuh, Ini 2 Komoditas Andalannya," Kalimantan, 20 Maret 2019 [Online]. Tersedia: https://kalimantan.bisnis.com/read/20190320/408/902485/ ekspor-kalsel-terus-tumbuh-ini-2-komoditas-andalannya [Diakses : 1 November 2019].

[25] S.S. Rita, "Kajian Zonasi Daerah Potensi Batubara untuk Tambang Dalam Provinsi Kalimantan Selatan Bagian Tengah," Pemaparan Hasil Kegiatan Lapangan Subdit Batubara, Zonasi Batubara Kalsel, 2005.

[26] Brady, H.G. Barry, E.T. Brown, Rock Mechanics For Underground Mining. Springer. 2006. 